\title{
First record of Pseudoterranova decipiens (Nematoda, Anisakidae) infecting the Red spot emperor Letbrinus lentjan in the Red Sea
}

Primeiro registro de Pseudoterranova decipiens (Nematoda, Anisakidae) infectando o imperador da mancha vermelha Lethrinus lentjan no Mar Vermelho

\author{
Saleh Al Quraishy1* (1); Rewaida Abdel-Gaber ${ }^{1,2}$ (1); Mohamed Abdel Monem Dkhil ${ }^{1,3}$ (1) \\ ${ }^{1}$ Zoology Department, College of Science, King Saud University, Riyadh, Saudi Arabia \\ ${ }^{2}$ Zoology Department, Faculty of Science, Cairo University, Cairo, Egypt \\ ${ }^{3}$ Department of Zoology and Entomology, Faculty of Science, Helwan University, Cairo, Egypt
}

Received May 21, 2019

Accepted June 25, 2019

\begin{abstract}
The current parasitological study was carried out to investigate helminth parasites infecting the Red spot emperor Lethrinus lentjan inhabiting Hurghada City at the Gulf of Suez, Red Sea, Egypt. Third-stage larvae of nematode parasite was isolated from the intestine as well as body cavity of the examined fish. Light and scanning electron microscopy revealed that this parasite belonged to Anisakidae family within the genus Pseudoterranova. The present species is named Pseudoterranova decipiens based on the presence of triangular mouth aperture with prominent boring teeth and soft swellings of the cuticle, long muscular esophagus, ventrally excretory pore, and narrow transverse slit of anal opening followed by a short mucron. The morphological characteristics of this species were confirmed by molecular analysis of $18 \mathrm{~S}$ rDNA gene region of the present parasite. It demonstrated a close identity $\geq 89 \%$ with taxa under family Anisakidae, $85 \%$ with Raphidascarididae, and $79-84 \%$ with Toxocaridae. A preliminary genetic comparison between gene sequence of the present parasite and other oxyurid species placeed it as a putative sister taxon to other Pseudoterranova decipiens described previously. This study demonstrated that the $18 \mathrm{~S} \mathrm{rDNA}$ gene region of Pseudoterranova decipiens yielded a unique sequence that confirmed its taxonomic position in Anisakidae.
\end{abstract}

Keywords: Marine fish, Lethrinus lentjan, Pseudoterranova spp., morphological studies, molecular analysis.

\section{Resumo}

O presente estudo parasitológico foi realizado para investigar os helmintos parasitos que infectam o peixe imperador Lethrinus lentjan, que habita a cidade de Hurghada no Golfo de Suez, Mar Vermelho, no Egito. Larvas de terceiro estágio de parasitos nematoides foram isoladas do intestino e da cavidade do corpo do peixe examinado. Microscopia eletrônica de luz e de varredura revelou que este parasita pertence à família Anisakidae dentro do gênero Pseudoterranova. A espécie atual é denominada Pseudoterranova decipiens baseada na presença de abertura triangular da boca com dentes proeminentes chatos e inchaços moles da cutícula, esôfago muscular longo, poro ventralmente excretor e fenda transversal estreita da abertura anal seguida por um mucron curto. As características morfológicas desta espécie foram confirmadas pela análise molecular da regiáo do gene $18 \mathrm{~S}$ rDNA do presente parasito. Demonstrou uma identidade próxima $\geq 89 \%$ com taxa sob família Anisakidae, 85\% com Raphidascarididae, e 79-84\% com Toxocaridae. Uma comparação genética preliminar entre a sequência genética do presente parasito e outras espécies de oxiurídeos coloca-o como um taxon irmão putativo para outros Pseudoterranova descritos anteriormente. Este estudo demonstra que a regiáo do gene $18 \mathrm{~S}$ rDNA de Pseudoterranova decipiens produz uma sequência única que confirma sua posiçáo taxonômica em Anisakidae.

Palavras-chave: Peixe marinho, Lethrinus lentjan, Pseudoterranova spp., estudos morfológicos, análise molecular.

\section{Introduction}

Anisakid nematodes have a global distribution among a wide variety of more than 200 marine fish species as intermediate host (MCCLELLAND et al., 1990) or as paratenic hosts (KØIE et al.,

*Corresponding author: Saleh Al Quraishy. Zoology Department, College of Science, King Saud University, Riyadh 11451, Saudi Arabia. e-mail: squraishy@ksu.edu.sa
1995; KUHN et al., 2011). Cephalopod, marine mammals, and humans can become accidental hosts for anisakids by ingesting fish infected with third-stage larvae and their prevalence's can be very high (WHARTON et al., 1999; ABOLLO et al., 2001; MCCLELLAND, 2002; SZOSTAKOWSKA et al., 2002). The life cycles of marine ascaridoid nematodes involve a number of stages 
and hosts. Adult and other life stages of these anisakid nematodes can be found in almost any part of the fish including the body cavity, internal organs, swim bladder, deeper layers of the skin or fins and external muscle layers (SMITH \& WOOTTEN, 1978; MATTIUCCI et al., 2008). Rocka (2004) followed by Nada \& Abd El-Ghany (2011) stated that anisakid nematodes commonly found in bony fish are represented by the following genera: Anisakis (Dujardin, 1845), Contracaecum (Railliet \& Henry, 1912), Hysterothylacium (Ward \& Magath, 1917), Paranisakiopsis (Yamaguti, 1941) and Pseudoterranova (Mozgovoy, 1951). Anisakid larvae are usually very difficult to identify species using morphology due to the lack of differential characters, but when adults are described and genetically characterized, then such larva assigned to a species based on molecular studies (MATTIUCCI et al., 1997).

Anisakid nematodes belonging to the Pseudoterranova decipiens species complex (also known as sealworms or codworms) mature and reproduce in the digestive tract of pinnipeds (LAUCKNER, 1985; DI AZEVEDO et al., 2017; IRIGOITIA et al., 2018). As far as it has been known, the life cycle of Pseudoterranova species also includes crustaceans as the first hosts, and fish as second hosts (SUKHDEO, 2012). Third-stage larvae (L3) of sealworms have commonly been reported in marine teleosts worldwide (GEORGE-NASCIMENTO, 1987; MATTIUCCI \& NASCETTI, 2008). The complex of Pseudoterranova decipiens is composed of six sibling species with four species occurring in the Northern Hemisphere are namely Pseudoterranova azarasi (Yamaguti \& Arima, 1942), Pseudoterranova bulbosa (Cobb, 1888), Pseudoterranova decipiens sensu stricto (s.s.) (Krabbe, 1868), and Pseudoterranova krabbei Paggi et al. (2000). While, Mattiucci \& Nascetti (2008) reported that the remaining two species present in the Southern Hemisphere are namely Pseudoterranova cattani (George-Nascimento \& Urrutia, 2000), and Pseudoterranova decipiens Bullini et al. (1997). Additional species in the genus Pseudoterranova include Pseudoterranova cattani, identified using allozyme markers in the Pacific (SUKHDEO, 2012).

Therefore, the present study aimed to report the natural occurrence of anisakid nematodes in the Red spot emperor Lethrinus lentjan. Additionally, identify the recovered worms by using light and scanning electron microscopy in order to determine its characteristic morphology, which may contribute valuable information to knowledge of the anisakids. Also, clarify the taxonomic position of the present anisakid nematodes using molecular phylogenetic analysis.

\section{Materials and Methods}

\section{Fish samples collection and parasitological examinations}

Forty two specimens of the Red spot emperor Lethrinus lentjan (Family: Lethrinidae) were collected during the period of August 2017-May 2018 from boat landing sites and fishermen of Hurghada City at the Gulf of Suez, Red Sea, Egypt. The collected fish specimens were transported immediately to the Laboratory of Parasitology Research at Zoology Department, Faculty of Science, Cairo University, Egypt, using special boxes for parasitological examination. All procedures contributing to this work comply with the ethical standards authorized by the Institutional Animal Care and Use Committee (IACUC) at Faculty of Science, Cairo University in Egypt with no. CUFS/S/Para/38/2014.
Gross microscopic examinations of all abdominal fish organs were done. The contents of the digestive tract were examined under a binocular microscope for the detection of any parasitic worms, which then removed with a fine forceps or a pipette. After isolation of parasitic worms from the infected fish, washing several times with an isotonic saline solution was done to get rid of any mucous and debris wastes. Isolated worms were fixed in $70 \%$ ethanol and subsequently clarified with lactophenol for morphological identification, in accordance with standard reference keys (PETTER \& QUENTIN, 2009). Parasite prevalence was calculated according to Bush et al. (1997). Photomicrographs of adult specimens were made with the aid of microscope Leica DM 2500 (NIS ELEMENTS software, ver. 3.8) in the Laboratory of Parasitology Research in Zoology Department, College of Science, King Saud University, Riyadh, Saudi Arabia.

For scanning electron microscope, some of nematode worms were fixed with 3\% buffered glutaraldehyde, dehydrated in ascending series of ethyl alcohol (70\%, 80\%, 95\%, 100\%), infiltrated with amyl acetate, processed in a critical point dryer "LEICA, EM CPD300", sputter-coated with gold-palladium in a gold sputtering system (JEOL, JEC-3000FC) for $30 \mathrm{~s}$ at $-70 \mathrm{~m}$ Torr pressure, and finally examined under an Etec Autoscan at $10-\mathrm{kV}$ JEOL scanning electron microscope (JSM-6060LV). Measurements were carried out in millimeters, presented as a range followed by the arithmetic mean $\pm S D$ in parentheses, and unless otherwise were stated.

\section{Molecular analysis}

gDNA was extracted from ethanol-preserved samples by using Qiagen DNeasy ${ }^{\mathrm{TM}}$ tissue kit according to the manufacturer's protocol. PCR reaction was carried out to amplify the target gDNA using the previously mentioned primers of NC5 (5'-GTA GGT GAA CCT GCG GAA GGA TCA TT-3') and NC2 (5'-TTA GTT TCT TTT CCT CCG CT-3') by Nadler et al. (2005). PCR reactions $(25 \mu \mathrm{l})$ were performed in $2 \mathrm{mM} \mathrm{MgCl}_{2}, 0.2 \mathrm{mM}$ each of dNTPs, $2.5 \mu \mathrm{l} 10 \times$ rTaq DNA buffer, $2.5 \mu \mathrm{M}$ of each primer, $1.25 \mathrm{U}$ rTaq polymerase buffer, $1 \mu \mathrm{l}$ of DNA sample and completed to $25 \mu \mathrm{l}$ with dist. $\mathrm{H}_{2} \mathrm{O}$ in a thermocycler (BioRad) under the following conditions: $94^{\circ} \mathrm{C}$ for $5 \mathrm{~min}$ (initial denaturation), then 35 cycles of $1 \mathrm{~min}$ at $94^{\circ} \mathrm{C}$ (denaturation), $1 \mathrm{~min}$ at $50^{\circ} \mathrm{C}$ (annealing), and $1 \mathrm{~min}$ at $72^{\circ} \mathrm{C}$ (extension) and finally post-PCR extension was carried out for $7 \mathrm{~min}$ at $72{ }^{\circ} \mathrm{C}$. Amplicons were sequenced using ABI Prism Dye Terminator Cycle Sequencing Core Kit (Applied Biosystems; Thermo Fisher Scientific, Waltham, MA, USA) with 310 Automated DNA Sequencer (Applied Biosystems, USA). To identify related sequences, a BLAST search was carried out on NCBI database. GenBank accession numbers of additional sequences utilized in the analyses were Pseudoterranova decipiens (gb| KF806033.1, U94766.1, JQ673263.1), Pseudoterranova sp. (gb| KC013597.1), Terranova caballeroi (gb| U94767.1), Anisakis typica (gb| HF911524.1), Anisakis simplex (gb| LL324431.1), Phocascaris sp. (gb| AF226575.1), Contracaecum radiatum (gb|AF226577.1), Contracaecum multipapillatum (gb|AF226574.1), Hysterothylacium fortalezae (gb| U94760.1), Raphidascaris acus (gb| AY821772.1), Toxocara cati (gb| JN256994.1), and Toxocara canis (gb| JN256996.1). Data of DNA sequences were aligned using CLUSTAL-X multiple sequence alignment. The alignment will be corrected manually using the alignment editor of 
software BioEdit 4.8.9 (HALL 1999). A phylogenetic tree was reconstructed using MEGA ver. 7.0 by using maximum parsimony (neighbour-interchange [CNI] level 3, random addition trees 100). To evaluate the robustness of the tree topologies, bootstrap analysis was performed based on 1000 replicates.

\section{Results}

Thirty one $(73.80 \%)$ out of forty two specimens of the Red spot emperor Lethrinus lentjan (Family: Lethrinidae) were found to be infected with anisakid nematoda parasite. The infection was recorded in the intestine as well as the body cavity of the examined fish. The infection was increased during summer to be $95.23 \%$ (20 out of 21 ) followed by winter season to be $52.38 \%$ (11 out of 21 ). The number of parasites per fish was ranged from 8 to 16 .

Description (Figures 1-10)

The body of the recovered third-stage larvae was yellowish to reddish in color, medium-sized, and elongated. Body measured 6.8-8.6 (7.2 \pm 1.1$) \mathrm{mm}$ in length and 0.16-0.21 $(0.18 \pm 0.01) \mathrm{mm}$ in width. The anterior end is rounded with triangular mouth aperture. Lips were absent with prominent boring teeth at the

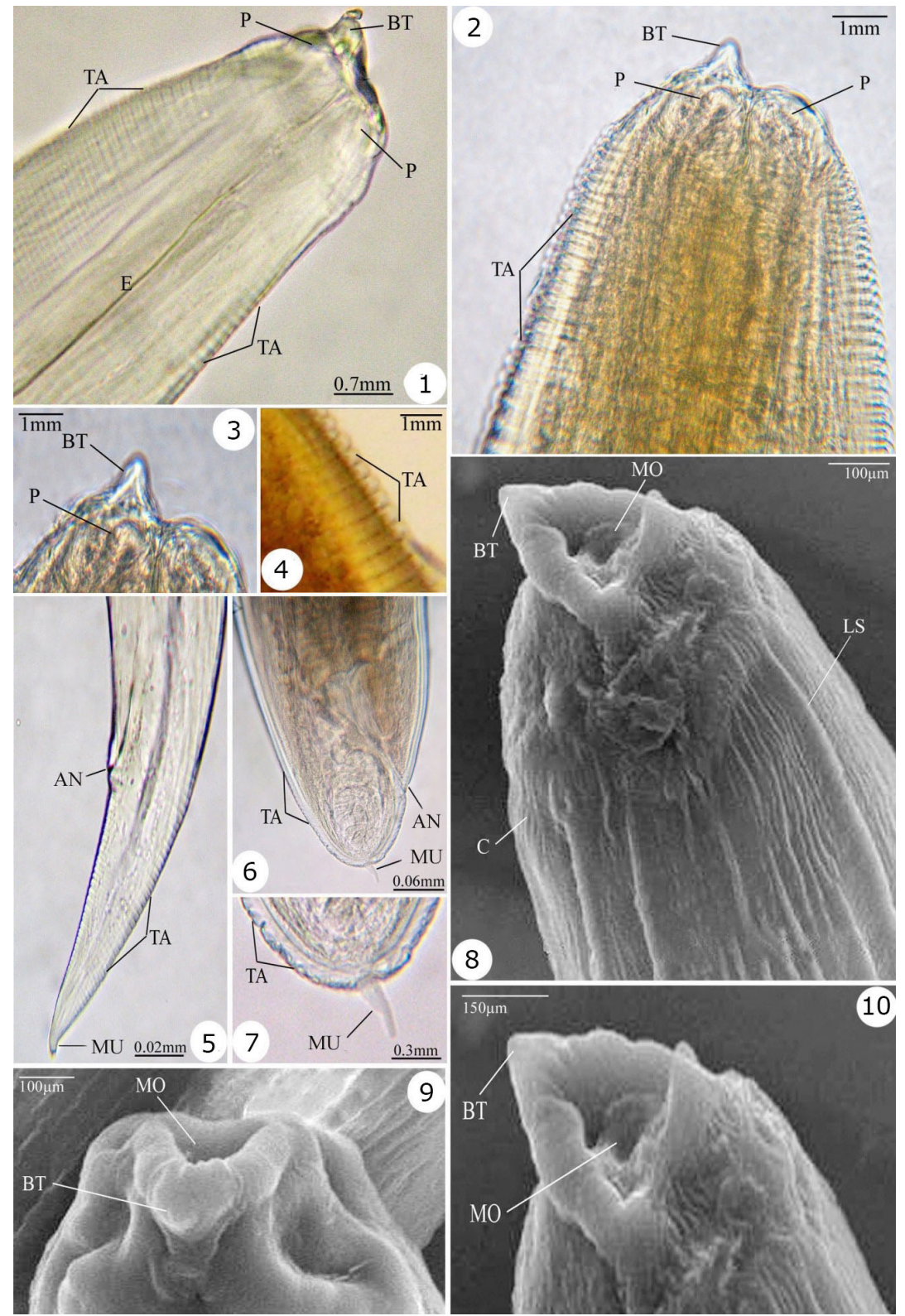

Figures 1-10. Photomicrographs of Pseudoterranova decipiens third-stage larvae recovered during the period of this study from Lethrinus lentjan inhabiting Hurghada City at the Gulf of Suez, Red Sea, Egypt; showing high magnifications of: 1-3 Anterior end with boring tooth (BT), papillae (P), esophagus (E) and clear appearance of transverse annulations (TA) of the cuticle (C). 4 Transverse annulations (TA) of the cuticle. 5 Posterior end of juvenile with anus (AN) and mucron (MU). 6,7 Posterior ends of larva with short mucron (MU). Figs. 8-10 Scanning electron micrographs for the anterior end of Pseudoterranova decipiens showing boring tooth (BT), mouth opening (MO), and clear appearance of longitudinal striations (LS) of the cuticle. 
anterior extremity provided with soft swellings of the cuticle at the level of papillae surrounding the tri-radiate mouth opening. The worm's esophagus had a long anterior muscular part, 0.79-0.96 $(0.91 \pm 0.01) \mathrm{mm}$ long. The excretory pore opened ventrally, below the boring teeth at the anterior end. The covering cuticle was rigid with transverse annular striations. The anal opening was in the form of a fairly long and narrow transverse slit. Tail was short, conical, pointed, $0.10-0.20(0.15 \pm 0.01) \mathrm{mm}$ long. The worm body ended by a short mucron, 0.01-0.03 (0.02 \pm 0.002$) \mathrm{mm}$ long.

\section{Molecular analysis}

A total of $350 \mathrm{bp}$ of $18 \mathrm{~S}$ rDNA gene sequence with $54.6 \%$ $\mathrm{GC}$ content was recovered from the present anisakid species and deposited in GenBank (gb| KR864891.1). Pairwise comparison of the nucleotide sequences and divergence showed that the present anisakid species revealed sequence identities $\geq 89 \%$ with taxa under family Anisakidae, 85\% with Raphidascarididae, and 79-84\% with Toxocaridae. Among Anisakidae members, the maximum identity with low divergent values was recorded as $96 \%$ with the previously studied Pseudoterranova decipiens (gb| KF806033.1, U94766.1, JQ673263.1), followed by 95\% with Pseudoterranova sp. (gb| KC013597.1), 93\% with Anisakis simplex (gb| LL324431.1), 91\% with Anisakis typica (gb| HF911524.1), and 89\% with Terranova caballeroi (gb| U94767.1), which had the highest blast scores with small number of nucleotide differences (Figure 11). Phylogenetic analysis produced a neighbor-joining tree constructed with partial sequences consistently formed two major lineages (Figure 12). The first major clade represent monophyletic origin for Ascaridoidea species and consisted of two larger subclades, showed

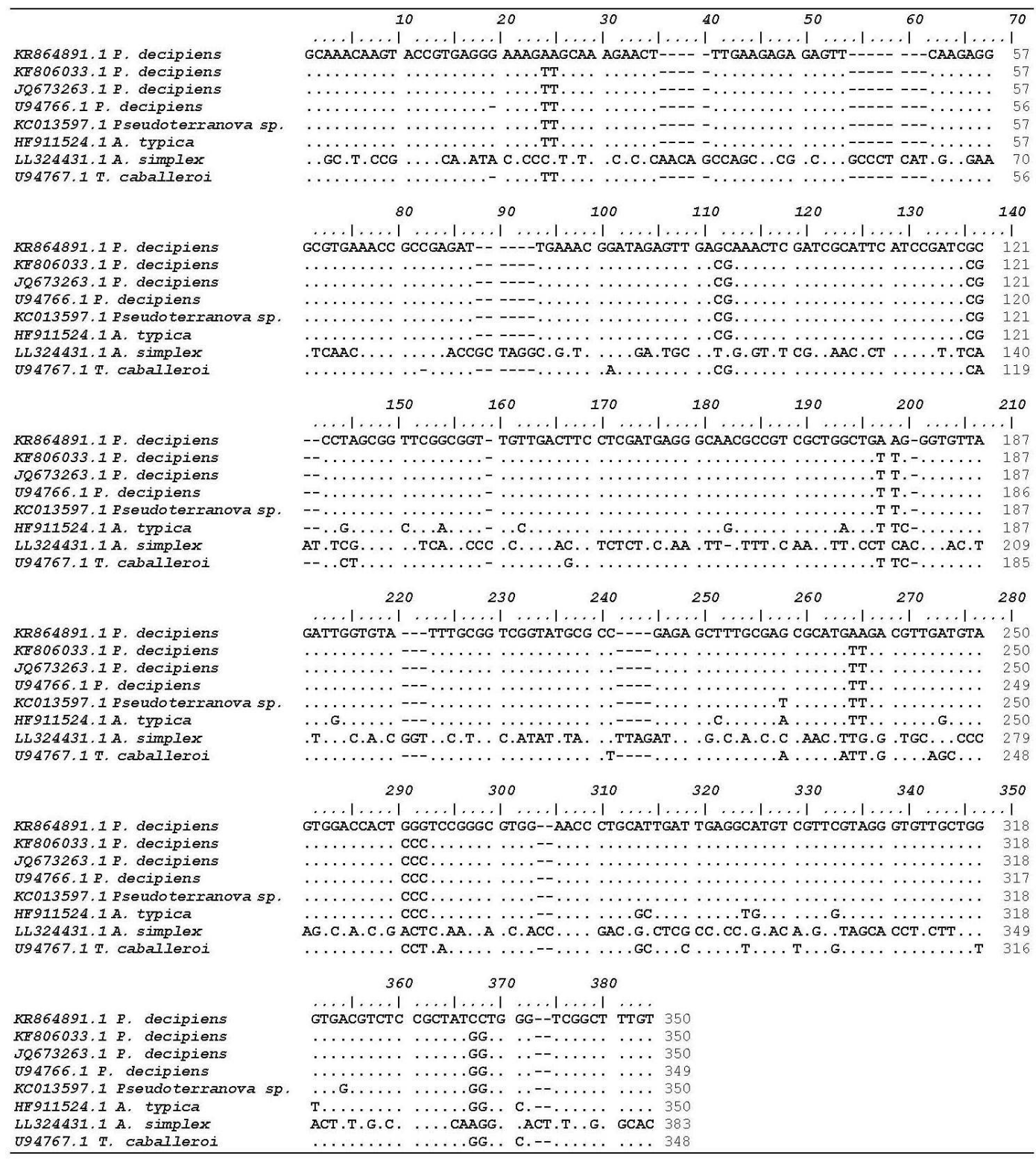

Figure 11. Sequence alignment of $18 \mathrm{~S}$ rDNA gene region of $P$. decipiens with the most closely related ansakid species. Only variable sites are shown. Dots represent bases identical to those of the first sequences, and dashes indicate gaps. 


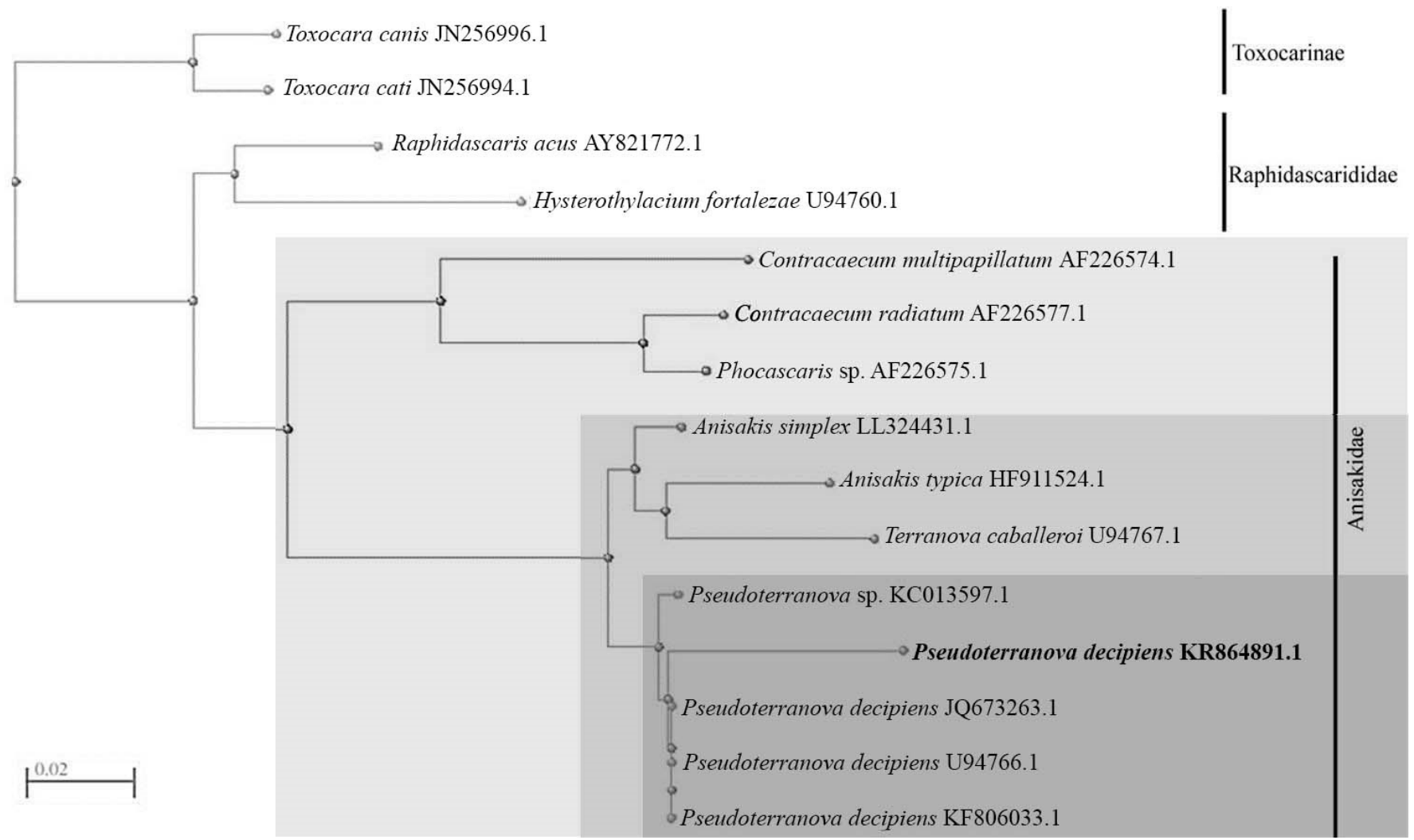

Figure 12. Molecular Phylogenetic analysis of the present Pseudoterranova decipiens third-stage larvae by Maximum Likelihood method based on the Kimura 2-parameter model. The tree with the highest log likelihood (-2014.41) is shown. The tree is drawn to scale, with branch lengths measured in the number of substitutions per site.

that Raphidascarididae (sampled genera included Raphidascaris and Hysterothylacium) being sister to Anisakidae (sampled genera included Anisakis, Pseudoterranova, Contracaecum, and Phocascaris). The other clade represents the monophyletic origin of Toxocaridae represented by genus Toxocara. Phylogenetic relationship showed that the present anisakid species is deeply embedded in the genus Pseudoterranova with close relationship to all previously studied species of Pseudoterranova species especially Pseudoterranova decipiens as a more related sister taxon.

\section{Discussion}

The anisakid nematode Pseudoterranova decipiens was recovered during the current study to infect the intestine as well as the body cavity of the Red spot emperor Lethrinus lentjan fish with $73.80 \%$ as a percentage of infection. This observation agreed with data obtained by Klimpel \& Palm (2011) followed by Najda et al. (2018) whom stated that the digestive tract considered as the preferred site of anisakid infection in marine mammals. The rate of parasitic infection increased during summer and fall during winter; these results coincided with data obtained by Ólafsdóttir \& Hauksson (1998) who stated that the common seal infected by Pseudoterranova decipiens with a percentage of $44.7 \%$ and development of ascaridoid larvae are highly influenced by temperature and the generation time likely to be longer in the warm water.
The morphology of the present parasite has the same diagnostic generic features of genus Pseudoterranova by having an elongated body provided with a rounded anterior end with triangular mouth aperture provided with lateral boring teeth and ended by a short pointed tail with mucron. It was compared morphologically and morphometrically to other Pseudoterranova species recorded previously. Description of the present parasite species agreed much more with Pseudoterranova decipiens described previously by Timi et al. (2001) from Engraulis anchoita in morphological and morphometric data of the different body parts. In addition, it resembled to records of Felizardo et al. (2009) from Paralichthys isosceles, Piña-Vázquez et al. (2012) from Lophius gastrophysus with little difference in measurements.

Molecular approaches to delimiting and identifying anisakid nematodes have markedly influenced our understanding of their systematics and biodiversity (NADLER \& HUDSPETH, 1998, 2000; NADLER et al., 2000; KELLERMANNS et al., 2007; BRUNET et al., 2017). In the present study, a nuclear rDNA region of 350 bp was amplified by using NC5 and NC2 primers and revealed sequence similar to homologous regions within the nuclear ribosomal sequence of other Pseudoterranova decipiens described previously. Apparently, the tree estimated in this study strongly supported several of the higher taxonomic groups. Phylogenetic tree constructed with partial sequences consistently formed two major lineages one represent monophyletic origin 
for Ascaridoidea species and consisted of two larger subclades, showed that Raphidascarididae is a sister group to Anisakidae with low genetic variations between them; while, the other clade represent the monophyletic origin of Toxocaridae, these results are in accordance with that obtained by Paggi et al. (2000) followed by Abollo et al. (2003), Nadler et al. (2005), Kellermanns et al. (2007) and Madanire-Moyo \& Avenant-Oldewage (2013). The MP tree supported the taxonomic position of the present Pseudoterranova species which is deeply embedded in the genus Pseudoterranova with a close relationship with other Pseudoterranova decipiens described previously as a more related sister taxon. Therefore, this anisakid species has a unique genetic sequence for one of Pseudoterranova species. Therefore, it could be concluded that the parasite species found in Lethrinus lentjan was identified as Pseudoterranova decipiens with a unique genetic sequence and having new locality records in Egyptian water.

\section{Acknowledgements}

Authors extend their appreciation to the Deanship of Scientific Research at King Saud University for funding this work through research group no (RG-002).

\section{References}

Abollo E, D'Amelio S, Pascual S. Fitness of the marine parasitic nematode Anisakis simplex s. str. in temperate waters of the NE Atlantic. Dis Aquat Organ 2001; 45(2): 131-139. http://dx.doi.org/10.3354/dao045131. PMid:11463100.

Abollo E, Paggi L, Pascual S, D’Amelio SD. Occurrence of recombinant genotypes of Anisakis simplex s.s. and Anisakis pegreffi (Nematoda: Anisakidae) in an area of sympatry. Infect Genet Evol 2003; 3(3): 175-181. http://dx.doi.org/10.1016/S1567-1348(03)00073-X. PMid:14522181.

Brunet J, Pesson B, Royant M, Lemoine JP, Pfaff AW, Abou-Bacar A, et al. Molecular diagnosis of Pseudoterranova decipiens s.s in human, France. BMC Infect Dis 2017; 17(397): 1-5. http://dx.doi.org/10.1186/ s12879-017-2493-7. PMid:28583155.

Bush AO, Lafferty KD, Lotz JM, Shostak AW. Parasitology meets ecology on its own terms: Margolis et al. revised. J Parasitol 1997; 83(4): 575-583. http://dx.doi.org/10.2307/3284227. PMid:9267395.

Di Azevedo MIN, Carvalho VL, Ińiguez AM. Integrative taxonomy of anisakid nematodes in stranded cetaceans from Brazilian waters: an update on parasite's hosts and geographical records. Parasitol Res 2017; 116(11): 3105-3116. http://dx.doi.org/10.1007/s00436-017-5622-8. PMid:28975458.

Felizardo NN, Menezes RC, Tortelly R, Knoff M, Pinto RM, Gomes DC. Larvae of Hysterothylacium sp. (Nematoda: Anisakidae) in the sole fish Paralichthys isosceles Jordan, 1890 (Pisces: Teleostei) from the littoral of the State of Rio de Janeiro, Brazil. Vet Parasitol 2009; 166(1-2): 175177. http://dx.doi.org/10.1016/j.vetpar.2009.08.004. PMid:19713041.

George-Nascimento M. Ecological helminthology of wildlife animal hosts from South America: a literature review and a search for patterns in marine food webs. Rev Chil Hist Nat 1987; 60: 181-202.

Hall TA. BioEdit: a user-friendly biological sequence alignment editor and analysis program for Windows 95/98/NT. Nucleic Acids Symp Ser 1999; 41: 95-98.
Irigoitia MM, Braicovich PE, Lanfranchi AL, Farber MD, Timi JT. Distribution of anisakid nematodes parasitizing rajiform skates under commercial exploitation in the Southwestern Atlantic. Int J Food Microbiol 2018; 267: 20-28. http://dx.doi.org/10.1016/j.ijfoodmicro.2017.12.009. PMid:29277002.

Kellermanns E, Klimpel S, Palm HW. Molecular identification of ascaridoid nematodes from the deep-sea onion-eye grenadier (Macrourus berglax) from the East Greenland Sea. Deep Sea Res Part I Oceanogr Res Pap 2007; 54(12): 2194-2202. http://dx.doi.org/10.1016/j.dsr.2007.09.001.

Klimpel S, Palm HW. Anisakid nematode (Ascaridoidea) life cycles and distribution: increasing zoonotic potential in the time of climate change? In: Mehlhorn H, editors. Progress in Parasitology. Parasitology Research Monographs, Volume 2. Heidelberg: Springer; 2011. p. 201-222.

Køie M, Berland B, Burt MDB. Development to third-stage larvae occurs in the eggs of Anisakis simplex and Pseudoterranova decipiens (Nematoda, Ascaridoidea, Anisakidae). Can J Fish Aquat Sci 1995;52(S1 Suppl.1): 134-139. http://dx.doi.org/10.1139/f95-519.

Kuhn T, García-Màrquez J, Klimpel S. Adaptive radiation within marine anisakid nematodes: a zoogeographical modeling of cosmopolitan, zoonotic parasites. PLoS One 2011; 6(12): e28642. http://dx.doi.org/10.1371/ journal.pone.0028642. PMid:22180787.

Lauckner G. Diseases of mammalia: Pinnipedia. In: Kinne O, editor. Diseases of marine animals. Volume IV, Part 2-Introduction, Reptilia, Aves, Mammalia. Hamburg: Biologische Anstalt Helgoland; 1985. p. 683-793.

Madanire-Moyo GN, Avenant-Oldewage A. On the development of a Parasitic Copepod, Lamproglena clariae Fryer, 1956 (Copepoda, Lernaeidae) infecting the sharp tooth cat fish, Clarias gariepinus. Crustaceana 2013 86(4): 416-436. http://dx.doi.org/10.1163/15685403-00003165.

Mattiucci S, Farina V, Campbell N, MacKenzie K, Ramos P, Pinto AL, et al. Anisakis spp. larvae (Nematoda: Anisakidae) from Atlantic horse mackerel: their genetic identification and use as biological tags for host stock characterization. Fish Res 2008; 89(2): 146-151. http:// dx.doi.org/10.1016/j.fishres.2007.09.032.

Mattiucci S, Nascetti G, Cianchi R, Paggi L, Arduino P, Margolis L, et al. Genetic and ecological data on the Anisakis simplex complex, with evidence for a new species (Nematoda, Ascaridoidea, Anisakidae). J Parasitol 1997; 83(3): 401-416. http://dx.doi.org/10.2307/3284402. PMid:9194819.

Mattiucci S, Nascetti G. Advances and trends in the molecular systematic of anisakid nematodes, with implications for their evolutionary ecology and host-parasite co-evolutionary processes. Adv Parasitol 2008; 66: 47-148. http://dx.doi.org/10.1016/S0065-308X(08)00202-9. PMid:18486689.

McClelland G, Misra RK, Martell DJ. Larval anisakine nematodes in various fish species from Sable Island Bank and vicinity. Can Bull Fish Aquat Sci 1990; 222: 83-118.

McClelland G. The trouble with sealworms (Pseudoterranova decipiens) species complex, (Nematoda): a review. Parasitology 2002;124(7 Suppl): 183-203. http://dx.doi.org/10.1017/S0031182002001658. PMid:12396224.

Nada MSM, Abd El-Ghany AM. Anisakid nematodes in marine fishes. J Am Sci 2011; 7(9): 1000-1005.

Nadler SA, Adams BJ, Lyons ET, DeLong RL, Melin SR. Molecular and morphometric evidence for separate species of Uncinaria (Nematoda: Ancylostomatidae) in California sea lions and northern fur seals: hypothesis testing supplants verification. J Parasitol 2000; 86(5): 1099-1106. http:// dx.doi.org/10.1645/0022-3395(2000)086[1099:MAMEFS]2.0.CO;2. PMid:11128487. 
Nadler SA, D’Amelio S, Dailey MD, Paggi L, Siu S, Sakanari JA. Molecular phylogenetics and diagnosis of Anisakis, Pseudoterranova, and Contracaecum from northern pacific marine mammals. J Parasitol 2005; 91(6): 14131429. http://dx.doi.org/10.1645/GE-522R.1. PMid:16539026.

Nadler SA, Hudspeth DSS. Ribosomal DNA and phylogeny of the Ascaridoidea (Nemata: Secernentea): implications for morphological evolution and classification. Mol Phylogenet Evol 1998; 10(2): 221-236. http://dx.doi.org/10.1006/mpev.1998.0514. PMid:9878233.

Nadler SA, Hudspeth DSS. Phylogeny of the Ascaridoidea (Nematoda: Ascaridida) based on three genes and morphology: hypotheses of structural and sequence evolution. J Parasitol 2000; 86(2): 380-394. http://dx.doi.org/10.1645/0022-3395(2000)086[0380:POTANA]2.0. CO;2. PMid:10780561.

Najda K, Kijewska A, Kijewski T, Plauška K, Rokicki J. Distribution of ascaridoid nematodes (Nematoda: Chromadorea: Ascaridoidea) in fish from the Barents Sea. Oceanologic Hydrobiologic stud 2018; 47(2): 128139. https://doi.org/10.1515/ohs-2018-0014.

Ólafsdóttir D, Hauksson E. Anisakidae nematodes in the common seal (Phoca vitulina L.) in Icelandic waters. Sarsia 1998; 83(4): 309-316. http://dx.doi.org/10.1080/00364827.1998.10413690.

Paggi L, Mattiucci S, Gibson DI, Berland B, Nascetti G, Cianchi R, et al. Pseudoterranova decipiens species A and B (Nematoda, Ascaridoidea): nomenclatural designation, morphological diagnostic characters and genetic markers. Syst Parasitol 2000; 45(3): 185-197. http://dx.doi. org/10.1023/A:1006296316222. PMid:10768762.
Petter AJ, Quentin JC. Oxyuroidea. In: Anderson RC, Chabaud AG, Willmott S. Keys to the nematode parasites of vertebrates: archival volume. London: CAB International; 2009. p. 218-247. http://dx.doi.org/10.1 079/9781845935726.0218.

Piña-Vázquez C, Reyes-López M, Ortiz-Estrada G, de la Garza M, Serrano-Luna J. Host-Parasite Interaction: parasite-derived and induced proteases that degrade human extracellular matrix. J Parasitol Res 2012; 2012: 1-63. http://dx.doi.org/10.1155/2012/748206. PMid:22792442.

Rocka A. Nematodes of the Antarctic fishes. Pol Polar Res 2004; 25(2): 135-152.

Smith JW, Wootten R. Anisakis and anisakiasis. Adv Parasitol 1978; 16: 93163. http://dx.doi.org/10.1016/S0065-308X(08)60573-4. PMid:364959.

Sukhdeo MVK. Where are the parasites in food webs? Parasit Vectors 2012; 5(239): 1-17. http://dx.doi.org/10.1186/1756-3305-5-239. PMid:23092160.

Szostakowska B, Myjak P, Kur J. Identification of anisakid nematodes from the southern Baltic Sea using PCR-based methods. Mol Cell Probes 2002; 16(2): 111-118. http://dx.doi.org/10.1006/mcpr.2001.0391. PMid:12030761.

Timi JT, Sardella NH, Navone GT. Parasitic nematodes of Engraulis anchoita Hubbs et Marini, 1935 (Pisces, Engraulidae) off the Argentine and Uruguayan coasts, South West Atlantic. Acta Parasitol 2001; 46(3): 186-193.

Wharton DA, Hassall ML, Aalders O. Anisakis (Nematoda) in some New Zealand inshore fish. NZ J Mar Freshw Res 1999; 33(4): 643-648. http://dx.doi.org/10.1080/00288330.1999.9516907. 